\title{
Pulmonary metastatic calcification with respiratory insufficiency in patients on maintenance haemodialysis
}

\author{
E JUSTRABO, ${ }^{1}$ R GENIN, ${ }^{2}$ AND G RIFLE ${ }^{2}$ \\ From the Department of Pathology, Faculty of Medicine, 21033 Dijon CEDEX, ${ }^{1}$ and the \\ Clinique Medicale, Department of Nephrology, Hopital du Bocage, 21034 Dijon CEDEX, ${ }^{2}$ France
}

\begin{abstract}
A uraemic patient undergoing chronic haemodialysis developed diffuse metastatic pulmonary calcification and died from acute respiratory insufficiency after renal transplantation. Thirteen similar cases previously published are reviewed, with emphasis on the clinical and anatomical features of such calcinosis. The pathogenesis of this calcification in patients on maintenance haemodialysis and some rules for its prevention are discussed.
\end{abstract}

Metastatic calcification in chronic renal failure has been well known since Virchow's first work in 1855. Such pathological calcification is either visceral or non-visceral. The former affects the muscles, the myocardium, and the lungs, whereas the latter is arterial, subcutaneous, or paraarticular.

With the advent of haemodialysis the manifestations of metastatic calcification have become prominent. Davidson and Pendras (1967), McLachlan et al (1968), Smith et al (1969), Mootz et al (1973), and Giacobetti et al (1977) have reported several cases of pulmonary metastatic calcification in patients undergoing chronic haemodialysis. We describe the case of a uraemic patient treated by chronic haemodialysis then renal transplantation who developed diffuse pulmonary micronodular calcification responsible for death from pulmonary insufficiency.

\section{Case report}

In 1955 urinalysis showed proteinuria in a 15-yearold boy. In 1969 gout occurred in the big toe, the knees and the ankles (serum urate was $112 \mathrm{mg} / \mathrm{l}$ ). The blood pressure was $170 / 100 \mathrm{mmHg}$. Intravenous pyelography and retrograde cystography confirmed the diagnosis of advanced interstitial chronic nephritis with massive vesicorenal reflux. The blood urea was $110 \mathrm{mg} / 100 \mathrm{ml}$, creatinine clearance $12 \mathrm{ml} / \mathrm{min}$, and proteinuria $1 \mathrm{~g} / 24$ hours. A low protein diet and a sodium administration did not stop his deterioration. Chronic haemodialysis was started in March 1970. Twice a week the patient underwent an eight-hour haemodialysis period by means of a twin coil dialyser. Left nephroureterectomy was performed on 26 January 1971 with a view to transplantation later on. Microscopic examination showed advanced unclassified nephropathy and parietal calcifications of the tubules.

He continued to deteriorate, developing cardiac failure in 1972. Between then and 1975 he had a low serum calcium (mean $8.21 \pm 1 \cdot 11 \mathrm{mg} / 100 \mathrm{ml}$ ), and raised phosphate (mean $9.93 \pm 2.71 \mathrm{mg} / 100 \mathrm{ml}$ ) and magnesium $(2 \cdot 73 \pm 0.42 \mathrm{mg} / 100 \mathrm{ml})$. Finally, disseminated vascular calcification and demineralisation of the bones appeared in February 1975. Disseminated micronodular opacities of undetermined aetiology were progressively visible in the lungs. After five years of chronic haemodialysis, despite his poor medical condition, this patient was admitted for kidney transplantation. He could neither physically nor psychologically bear periodic haemodialysis.

A renal transplantation was performed on $7 \underset{7}{7}$ February 1975 with a cadaver-kidney with two identities and two incompatibilities in HLA sys- N tem. The cross match between the donor's lympho- $N$ cytes and the recipient's serum was of course $O$ negative. After 15 hours of cold ischaemia, diuresis $\omega$ restarted immediately. But two hours after the operation cyanosis and collapse with respiratory ${ }_{C}$ distress required the assistance of a respirator. This artificial ventilation had to be continued for ? eight days because of severe hypoxia that was con- $\frac{T}{0}$ nected with left lower lobe pneumonia. The fever $\frac{\vec{D}}{\mathbb{D}}$ fell with antibiotics, but the patient remained hypoxic after extubation, $\mathrm{PaO}_{2}$ between 55 and $\stackrel{\AA}{\varrho}$ $66 \mathrm{mmHg}$. The $\mathrm{PaCO}_{2}$ remained normal, and the 
Sao2 was about $82 \%$. At that time diuresis was more than $2.61 /$ day, serum creatinine $2.6 \mathrm{mg} /$ $100 \mathrm{ml}$, the urea $170 \mathrm{mg} / 100 \mathrm{ml}$ without evidence of rejection.

After a stormy course, during which anticoagulants were started, haemorrhage occurred into the graft, and the patient died on 23 February 1975.

\section{Post-mortem findings}

The lung lesions were the main gross findings. The right and left lungs, weighing respectively $970 \mathrm{~g}$ and $800 \mathrm{~g}$, were diffusely solidified and rigid. On cut sections numerous irregular greyish nodules were scattered through both lungs. These lesions were raised above the lung surface and were of gritty or firm consistency. They measured up to $0.5 \mathrm{~cm}$ in diameter. The heart weighed $520 \mathrm{~g}$ with left ventricular hypertrophy. Calcific deposits infiltrated the free edge of the anteromedial cusp of the mitral valve. The right kidney weighed $40 \mathrm{~g}$, and its yellowish tissue contained several simple cysts. The $220 \mathrm{~g}$ transplanted kidney was congested. Neither tumour nor hyperplasia of parathyroid glands were found.

Microscopic examination showed a diffuse metastatic calcification in both lungs. The septa of alveoli were thickened by fibrosis, calcification, and macrophagic giant cells (figs 1 and 2). Some alveolar spaces were filled with fibroblasts or calcific concretions. Smaller calcific granulations were also discovered in the walls of bronchi or bronchioles and in the media of arterioles or venules (figs 3 and 4). No myocardial or arterial calcification was seen after hemalum-phloxine-safranin and Von Kossa's stain. The right kidney was destroyed by advanced unclassified nephropathy, and

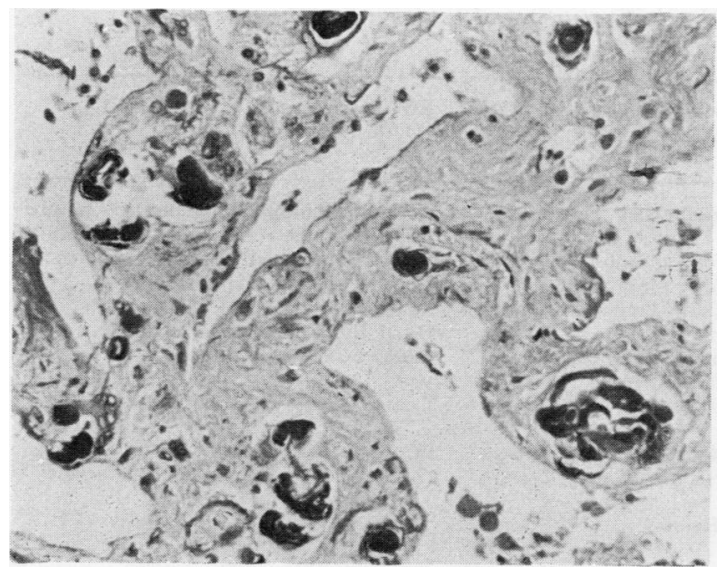

Fig 1 Lung, showing alveolar septa widened by fibrosis and calcification $(G r \times 275)$.

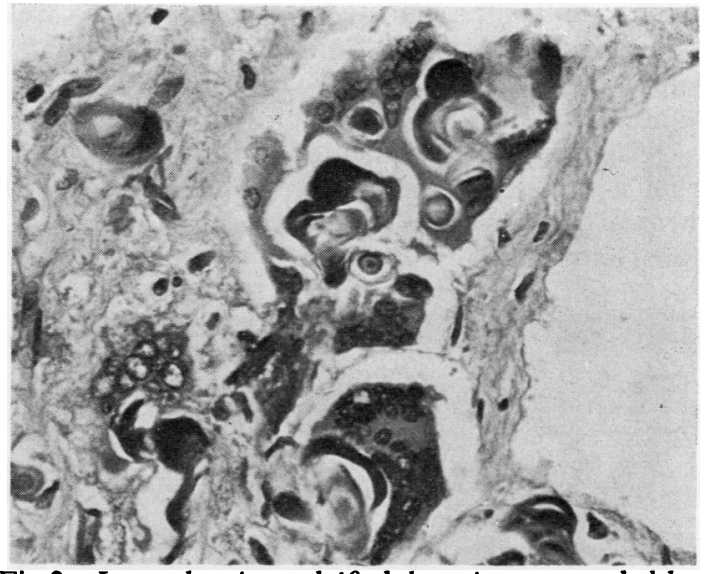

Fig 2 Lung showing calcified deposits surrounded by macrophagic giant cells and fibrosis $(\mathrm{Gr} \times 220)$.

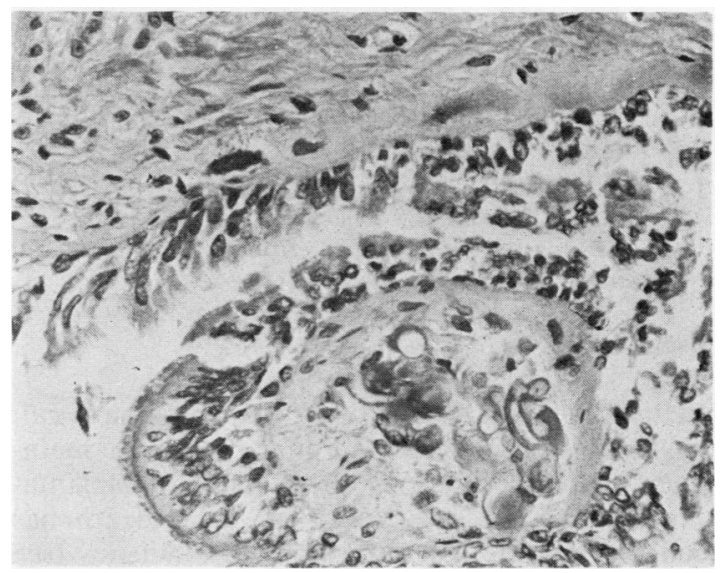

Fig 3 Bronchiole showing scattered calcification through the lamina propria $(G r \times 330)$.

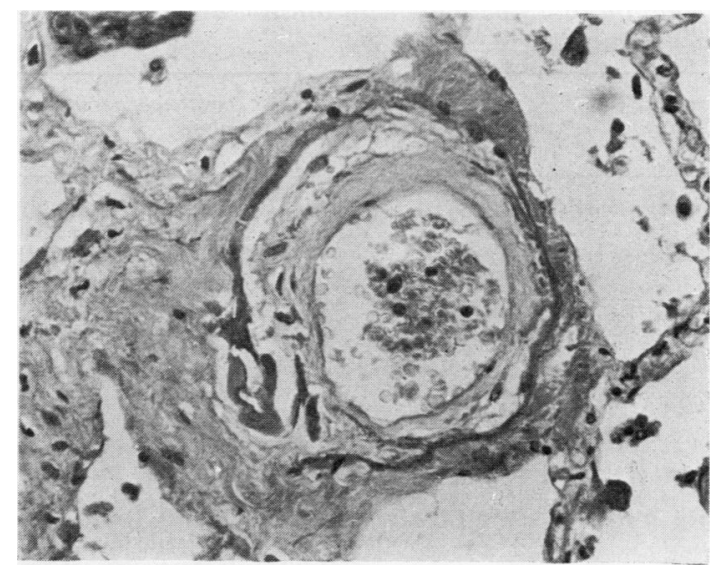

Fig 4 Wall of this arteriole or venule is destroyed by calcification $(G r \times 137)$. 
calcific infiltration affected the glomeruli as well as the basal membrane of numerous tubules (fig 5). Some simple cysts were also present. The transplanted kidney showed signs of acute rejection.

Diffuse pulmonary calcinosis had induced death from acute respiratory failure after five years of chronic haemodialysis and in the days after renal transplantation.

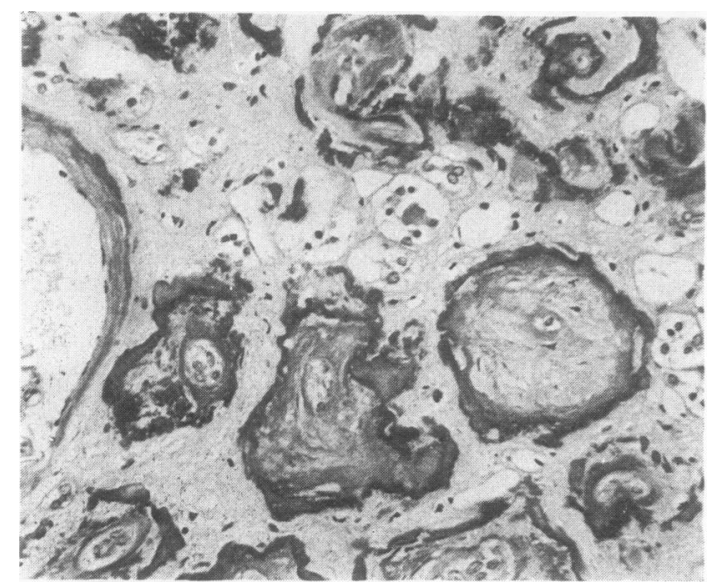

Fig 5 Kidney, showing calcification in basal membrane of numerous tubules $(\mathrm{Gr} \times 275)$.

\section{Discussion}

Thirteen similar cases with diffuse pulmonary calcinosis have been reported in patients on maintenance haemodialysis or after renal transplantation or both. In seven of these cases death has occurred from lethal respiratory insufficiency (see table).
The visceral calcinosis is rarely present initially and is often unrecognised during life. Usually the diagnosis is made several months after the beginning of chronic haemodialysis and there is no parallel between the duration of chronic renal failure and the occurence of calcinosis (Conger, 1975). In three cases calcific deposition has been diagnosed after renal transplantation (Kreis et al, 1976; Giacobetti et al, 1977).

Patients sometimes complain of effort dyspnoea but often there are no clinical signs. Diagnosis is usually based on pulmonary radiography. Sometimes calcinosis is predominant: calcified opacities of various size are seen in the two lung fields, occasionally associated with other visceral or nonvisceral calcifications (McLachlan et al, 1968; Boner et al, 1971). Often the calcifications are less than $2 \mathrm{~mm}$ diameter, but occasionally they form a conglomerate and look like oedema.

Pulmonary function tests give little information, but the anatomical changes due to calcific deposits may lead to a restrictive syndrome.

The evolution varies but is lethal in most cases. Death by acute respiratory failure occurred seven times (see table). Cardiac decompensation often worsens this failure. In other cases respiratory insufficiency is an aggravating factor. Favourable evolution is rare; in one case of reversible nephrotic syndrome with acute renal failure pulmonary calcification occurred and then disappeared with haemodialysis. Yet metastatic calcification has been discovered in patients on maintenance haemodialysis or after renal transplantation or both (Mootz et al, 1973; Kreis et al, 1976; Giacobetti et al, 1977).

A complete pathological study performed in 11

Evolution of 13 patients with diffuse metastatic pulmonary calcifications and undergoing chronic haemodialysis

\begin{tabular}{|c|c|c|c|c|c|}
\hline Authors & Cases & $\begin{array}{l}\text { Sex and } \\
\text { Age }\end{array}$ & $\begin{array}{l}\text { Duration of haemodialysis or peritoneal } \\
\text { dialysis }\end{array}$ & $\begin{array}{l}\text { Duration } \\
\text { of advanced } \\
\text { uraemia }\end{array}$ & Evolution \\
\hline Davidson and Pendras (1967) & & F, 34 & 3 years of twice weekly haemodialysis & 5 years & Death by acute cardiorespiratory failure \\
\hline & 2 & $\mathrm{M}, 32$ & 3 periods of haemodialysis & & Death by acute cardiorespiratory failure \\
\hline McLachlan et al (1968) & 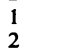 & F, 34 & 2 periods of haemodialysis for 1 month & $\begin{array}{l}7 \text { months } \\
2 \text { months }\end{array}$ & $\begin{array}{l}\text { Death by acute pulmonary insufficiency } \\
\text { Death by terminal renal failure }\end{array}$ \\
\hline & 3 & $\mathrm{M}, 16$ & 3 periods of peritoneal dialysis for 5 months & 5 months & Survived \\
\hline Smith et al (1969) & 1 & M, 43 & Haemodialysis for 20 months & 3 years I & Death by terminal renal failure \\
\hline Boner et al (1971) & 1 & $\mathrm{~F}, 58$ & $\begin{array}{l}\text { Peritoneal dialysis or haemodialysis from } \\
\text { February to September } 1970\end{array}$ & 1 year & Death by acute liver necrosis \\
\hline \multirow[t]{2}{*}{ Mootz et al (1973) } & 1 & F, 24 & $\begin{array}{l}\text { Haemodialysis for one year. Binephrectomy. } \\
\text { Renal transplantation }\end{array}$ & $?$ & Death by acute pulmonary insufficiency \\
\hline & 2 & $F, 38$ & Four periods of peritoneal dialysis & 2 years & Death by acute pulmonary insufficiency \\
\hline Neef et al (1974) & 1 & M, 67 & $\begin{array}{l}4 \text { periods of peritoneal dialysis for two } \\
\text { years }\end{array}$ & 2 years & Death by acute pulmonary insufficiency \\
\hline Kreis et al (1976) & 1 & $\mathrm{~F}, 22$ & $\begin{array}{l}\text { Haemodialysis for } 3 \text { years. Renal } \\
\text { transplantation }\end{array}$ & 3 years & Survived \\
\hline & 2 & $\mathbf{M}, 17$ & Haemodialysis for 7 months & 6 years & Survived \\
\hline Giacobetti et al (1977) & 1 & M, 42 & Haemodialysis for 2 years & $?$ & Death by acute pulmonary insufficiency \\
\hline
\end{tabular}


cases showed similar lesions. The lungs are diffusely solidified. They are heavy and their weight varies from $590 \mathrm{~g}$ to $1800 \mathrm{~g}$. On cut sections irregular or well-delineated nodules are scattered through the lung. Microscopic examination shows a fibrous widening of the alveolar septa. Multiple areas of calcification and a few lymphocytes infiltrate these walls. The alveolar lumen is often filled with exudate or calcification, sometimes surrounded by fibroblast proliferation. Calcification is also observed in the wall of bronchioles and arteries. The heart of these patients is enlarged. It may show biventricular hypertrophy and calcifications on the aortic valvules or on the mitral valve. In three cases the microscopic examination showed myocardial fibrosis and metastatic calcification. In other cases calcification is seen only in the media of the coronary arteries. A slight rise in osteoclastic or osteoblastic activity was noticed in three patients. Two of them had enlarged parathyroid glands (Davidson and Pendras, 1967, cases 1 and 2). Mootz et al (1973) and Giacobetti et al (1977) reported bony changes as osteitis fibrosa cystica in patients with four grossly and microscopically hyperplastic parathyroid glands. Examination of the kidneys shows a large number of chronic renal diseases. The basal membrane of the tubules and of the glomerular capsules is often thickened by calcific deposits.

Three hypotheses of the pathogenesis are considered. Firstly, the calcification is part of the natural history of the renal insufficiency and is promoted by tissue damage, such as by the pulmonary oedema of our patient and of others (cases 1 and 2 of McLachlan). Several patients, however, have no evident antecedent pulmonary lesions. So the role of humoral disorders that are constant seems more important. In all the observations Ca X P product $(\mathrm{mg} / \mathrm{l})$ exceeds 4500 . If a predominant hypercalcaemia was noticed by Davidson and Pendras (1967) serum phosphate was highly increased in all the patients reported. The serum phosphate was $100 \mathrm{mg} / 100 \mathrm{ml}$ for several years.

On the other hand, the high serum magnesium of uraemic patients may explain the chemical nature of the visceral calcification. In these cases, Contiguglia et al (1973), using X-ray diffraction analysis of lung, heart, and muscle specimens, have shown that visceral calcification corresponds to an amorphous (Ca Mg)3 (PO 4)2 or whitlockite. Non-visceral and arterial calcifications are hydroxyapatite. Whitlockite is observed only in this medical condition (Gatter and McCarty, 1967). So the part played by magnesium seems to be prominent: this cation inhibits the crystalline growth of apatite and, in contrast, stabilises whitlockite formation by decreasing its temperature of formation.

The alkaline conditions of kidney and lung favour deposition. Then at lung level the variations of blood $\mathrm{pH}$ from 7.35 to $7 \cdot 45$ decreases the phosphocalcific salt solubility by $10 \%$. The severe changes of $\mathrm{pH}$ during haemodialysis may promote crystallisation.

It is difficult to specify the role of the hyperparathyroïdism which is constant in uraemic patients. A parallelism between parathyroid hyperplasia and non-visceral calcification must exist, however (Contiguglia et al, 1973). This is not so for visceral calcifications.

Sometimes renal transplantation may increase the calcific deposition by calciphylaxis (Selye, 1962). Calciphylaxis occurs after sensitisation of the organism with direct or indirect calcifiers, such as vitamin D and parathyroid hormone (Parfitt, 1969; Rubini et al, 1969). The calcification appears after a critical period-exposure to a challenger or a precipitating factor such as steroids, calcium, or albumin. Giacobetti et al (1977) consider that the rapid development after renal graft of pulmonary calcification with documentation of normal lung by radiography six days before death supports the concept of acute deposition by calciphylaxis.

The lethal character of these calcific deposits call for careful monitoring, control of blood calcium, phosphate, and magnesium being the probable way to prevent tissue damage. Our observations and the others suggest the importance of raised magnesium and the part played by the association of pulmonary haemodynamic disorders. We propose, like Moinuddin et al (1976) and Schlangen and Pauwels (1976), that dialysed patients with unexplained respiratory symptoms should undergo "bone scan" with ${ }^{99 m}$ Tc pyrophosphate for pulmonary calcifications. These authors think that bone scanning "is far more sensitive than conventional radiography for demonstration of pulmonary calcification." Finally, when visceral calcification is severe renal transplantation would seem the best solution. But we do not forget that this treatment can increase metastatic calcifications by calciphylaxis.

\section{References}

Boner, G, Jacob, E T, Pevzner, S, and Jungmann, A (1971). Diffuse calcification of lungs in a patient on maintenance hemodialysis. Israel Journal of Medical Sciences, 7, 1182-1187.

Conger, J D, Hammond, W S, Alfrey, A C, Contiguglia, S R, Standford, R E, and Huffer, W E 
(1975). Pulmonary calcification in chronic dialysis patients. Clinical and pathogenic studies. Annals of Internal Medicine, 83, 330-336.

Contiguglia, $\mathbf{S}$, Alfrew, A C, Miller, $\mathbf{N}$, Runnells, D E, and Le Geros, R Z (1973). Nature of soft tissue calcification in uremia. Kidney International, 4, 229-235.

Davidson, R C, and Pendras, J P (1967). Calciumrelated cardiorespiratory death in chronic hemodialysis. Transactions, American Society for Artificial Internal Organs, 13, 36-40.

Gatter, R A, and McCarty, D J (1967). Pathological tissue calcifications in man. Archives of Pathology, 84, 346-353.

Giacobetti, R, Feldman, S A, Ivanovitch, P, Huang, C M, and Levin, M L (1977). Sudden fatal pulmonary calcification following renal transplantation. Nephron, 19, 295-300.

Kreis, H, Broyer, M, Caubarrere, I, Bignon, J, Barbanel, C, and Crosnier, J (1976). Calcinoses pulmonaires au cours de la transplantation rénale. Bulletin de la Societé Médicale de Hauteville, 43, 137-140.

McLachlan, M S F, Wallace, M, and Senevirante, C (1968). Pulmonary calcification in renal failure. Report of three cases. British Journal of Radiology, 41, 99-106.

Moinuddin, M J, Rockett, J F, Weber, R A (1976). Scanning for pulmonary calcification. Annals of Internal Medicine, 84, 224-225.
Mootz, J R, Sagel, S S, Roberts, T H (1973). Roentgenographic manifestations of pulmonary calcifications. A rare case of respiratory failure in chronic renal disease. Radiology, 107, 55-60.

Neff, M, Yalcin, S, Gupta, S, and Berger, H (1974). Extensive metastatic calcification of the lung in an azotemic patient. American Journal of Medicine, 56, 103-109.

Parfitt, A M (1969). Soft-tissue calcification in uremia. Archives of Internal Medicine, 124, 544-553.

Rubini, M E, Coburn, J W, Massry, S G, and Shinaberger, J H (1969). Renal osteodystrophy. Archives of Internal Medicine, 124, 663-669.

Schlangen, J T, and Pauwels, E K J (1976). Die diagnostik der Calcinosis pulmonis durch szintigraphische Untersuchungen. Fortschr Geb Roentgenstr Nuklearmed, 124, 119-122.

Selye, H (1962). Calciphylaxis. University of Chicago Press, Chicago.

Smith, J C, Stanton, L W, Kramer, N C, and Parrish, A E (1969). Nodular pulmonary calcification in renal failure. Report of a case. American Review of Respiratory Diseases, 100, 723-728.

Virchow, R (1855). Kalk-Metastasen. Virchows Archiv für pathologische Anatomie und Physiologie, 8, 103-113; 9, 618-620.

Requests for reprints to: Dr E Justrabo, Department of Pathology, Faculty of Medicine, 21033, Dijon CEDEX, France. 